\title{
Effect of Education and Training, Discipline Working and Job Satisfaction of Members of the Organization of Work Performance Bonding Kindergarten Teacher Indonesia (IGTKI) SUB Krembung
}

\author{
Dewi Tri Wijayati Wardoyo ${ }^{1}$ \\ ${ }^{1}$ Management Studies Program Faculty of Economics, State University of Surabaya, Indonesia \\ Correspondence: Priyono, Educational Technology Graduate Program, University of PGRI Adi Buana Surabaya, \\ Indonesia, Dukuh Menanggal XII Surabaya, Indonesia. Tel: 62-812-1697-4878. E-mail: \\ priyono.unu_sidoarjo@yahoo.com
}

Received: November 3, 2015

Accepted: November 20, $2015 \quad$ Online Published: December 25, 2015

doi:10.5539/ijef.v8n1p187

URL: http://dx.doi.org/10.5539/ijef.v8n1p187

\begin{abstract}
This research attempts to know if there are no influence or between education and training discipline of work and the satisfaction work simultaneously and partial achievement work against member organization of IGTKI Krembung Distric. The population of this study is all member organization of IGTKI Krembung Distric and sample 98 employees. An instrument data collection is the questionnaire, and data analysis technique available for analysis is linear regression worship of idols with the program statistic spss.

This research result indicates that the education and training, discipline of work and the satisfaction of work achievement of work affecting employees simultaneously and partial.proven the analysis that shows the education and training that the value of work is 2,444 t-test 0,016 with a sig value so $(0,016 \&<0.05)$, discipline that the value of work is 2,947 t-test 0.004 with a sig value so $(0.004 \&<0.05)$, and the satisfaction of work is the value of t-test $0,0122,569$ with a sig value so $(0,012 \&<0.05)$ that means each variable $\mathrm{x}$ impact on the achievement of working.

But the results obtained by the simultaneous or f-test 7,045 with the significance of $0,000 \&<0.05$ so ho rejected ha accepted. So, can be concluded that the results of this research work is education and training, discipline of work and the satisfaction of work achievement of having influence in the work of employees. As we know that the education and training, discipline and satisfaction to improve the quality of work achievement and quality of the company.
\end{abstract}

Keywords: education and training, discipline, satisfaction of work, achievement of work

\section{Introduction}

In the application of disciplinary rules should be consistency if a good working attitude that improves job satisfaction to be achieved (Emiola, 2000). Given this Emiola view, Ukeje (2002) argued that the investigation adoption of the rules of education sometimes de-motivate the staff and the same effect on job satisfaction and agency staff ipso-factothe. Based on the above statement, Miskel (1988; cited in Igwe, 1999) asserts that there is a direct positive relationship between job satisfaction level lecturer and attitude to work. He mentioned a number of characteristics that are relevant to fulfilling the needs and satisfaction of one's work as the nature of work, pay, promotion, staff development, working conditions, etc.

In a study conducted by Olagboye (1998), 85 (85\%) percent of the 120 professors who were interviewed stated that disciplinary environment will help the staff to be happy in their work. He added that since strengthening this opinion, Ibanga (2004) stated that the faculty (staff) working attitude correlates to satisfaction or dissatisfaction as a happy worker to make sure he puts in the best provisional known lecturer satisfied unproductive or producing below its potential capacity or capability. Therefore, it is important assuming the role of discipline and attitude of staff job satisfaction that this study intends to examine critically.

Organizations (Robbins, Odendaal, \& Roodt, 2003). To resolve conflicts between individuals and groups, and to ensure a harmonious working environment, managers, supervisors and other leaders utilize disciplinary action to prevent escalation and to maintain industrial peace. Disciplinary action, in essence, is designed to improve behavior and to maintain balance in labor relations (Grogan, 2009). When the unwanted behavior or action is 
seen in the workplace, so that it is the prerogative of leaders and managers to correct this behavior and establish norms or standards are more acceptable than they were corrected (Rao, 2009). Therefore, the discipline and the next rule and The procedure is an integral part of the employment relationship between the employer and employee, but, in order to discipline to be effective and produce the desired results, need to be substantially and procedurally fair (Bendix, 2005). This means that the right rules and the process to be followed in the workplace to ensure that all organizational policy and legislative requirements are being adhered to. Substantial justice with regard to the reasons initiate disciplinary actions, causes of action. There must be a fair and equitable grounds to initiate disciplinary action, and it needs to comply with the organization's policy and announced in the labor laws of the country (Venter \& Levy, 2011). Procedural fairness relating to the improve the process to be followed during the investigation of disciplinary (Bendix, 2010). This refers to the organization's internal rules and processes that need to be followed step by step to ensure that employees' rights are not violated, and to protect the business against claims of labor practices are unfair and unjust dismissal. Ensure that both aspects of justice adopted is a difficult task for any manager or supervisor in the business. As this aspect must be obeyed, supervisors and managers alike need to ensure that policies and procedures were properly followed in this case. Leader so as to have an inherent responsibility to businesses to ensure that their actions were appropriate in the context of disciplinary action, and that they are at all times act in the best interests of the organization.

Lack of attention from the service make the most of the members of the District IGTKI Krembung will neglect the responsibility as a kindergarten teacher. Teachers Kindergarten are required as a creative teacher was not given enough space to do the teaching and learning activities in the institution, it would affect job performance member IGTKI district Krembung, there are several factors according to researchers that affect job performance member IGTKI District of Krembung.

\section{Theoretical Basis}

\subsection{Education and Training (Training)}

According to Pearl (2004, p. 41) defines training as a means used to provide or improve the skills needed to do the job now. Education and training are two very similar things mean execution, but the scope of that set it apart. According Siswanto Sastrohadiwiryo (2005, p. 199) education is a task to improve the knowledge, understanding or attitude of the workforce so that they can better adapt to their work environment. Education related to the general increase knowledge and understanding of the working environment. Education relates to answer how and why. Education is usually more associated with the theory of the work, while training is an education in the sense that rather narrow, especially with the instructions, special assignments and discipline. Training is a process of helping the workforce to acquire effectiveness in their job now or that will come through the development of the future through the development of habits of thought, action, skills, knowledge and attitude it deserves.

\subsection{Work Discipline}

Definition of discipline can be connoted as a punishment, despite the very real sense it is not. Discipline comes from the Latin "disciplina" which means training or education modesty and spirituality and character development. so the nature of the discipline concerned with the development of proper attitude towards work. Discipline is a strength that develops in the body's own workers that caused him to adapt voluntarily to the decisions, regulations, and high values of work and behavior (Asmiarsih, 2006, p. 23).

Understanding Discipline Work In the opinion of Alex S. Nitisemito (1984, p. 199) Discipline is an attitude of behavior and act in accordance with the regulations of the company both written and unwritten. According Moekijat (2005, p. 179) work discipline is sangfroid that set. In the opinion of T. Hani Handoko (1994, p. 208) Discipline is the management activities to execute organizational standards. Work discipline, Siswanto (1989) suggested the discipline of work as an attitude of respect, appreciate the dutiful and obedient to the rules that apply both written and unwritten and able to run and dodge accept sanctions if he violates the duties and authority given to her.

\subsection{Job Satisfaction}

Everyone who works expect to obtain satisfaction from work. Basically the job satisfaction is a matter that is individualized to each individual will have a level of satisfaction varies in accordance with the values prevailing in every individual. According Martoyo (2000, p. 142) job satisfaction is an emotional state employees who happen or not happen the meeting point between the remuneration that are desired by the employee. Davis and Newstrom (1985, p. 105) describes "job satisfaction is a set of unpleasant feelings about whether or not employees of their job". According Handoko (2002, p. 193): job satisfaction is an emotional state that is pleasant or unpleasant by which employees view their jobs. According to Robbins (2003, p. 78) job satisfaction is "the 
general attitude towards the work of someone who shows the difference between the number of awards received by workers and the amount that they believe they should receive".

From the opinions above it can be concluded that job satisfaction is the emotional state of a person who could be seen through the behavior and attitude of either a pleasant or unpleasant to the work they do.

\subsection{Work Performance}

Mangkunagara (2006, p. 50) states that work performance is the result of the quality and quantity of work achieved in executing their duties, in accordance with the responsibilities given to him. Achievement of work proposed by Kusryanto (in Hasibuan, 2005, p. 250) is a comparison of the results achieved with the participation of labor per unit time. Dharma (in Ruki, 2002, p. 121) suggests that work performance is something that is done or services produced or provided someone. Furthermore Ruki $(2002$, p. 121) says that in the covered work performance result, job performance is determined by the interaction between ability and motivation. Handoko (1997, p. 19) defines performance as an expression capability based on the knowledge, attitudes, skills and motivation to produce something. Furthermore Handoko (1997, p. 19) states work performance as an expression such as output, efficiency seta effectiveness is often associated with productivity. Based on some opinions above it can be concluded that the performance that can be achieved is the result of someone doing the job duties based on the knowledge, attitudes, skills and motivation.

\section{Conceptual Framework}

The conceptual framework of the following research is to describe a relationship or connection between the concept of one of the other concepts of the problem to be investigated. Then the conceptual framework that can serve with picture author between variables $\mathrm{X}$ or $\mathrm{Y}$ variables with variable or the dependent variable. The conceptual framework as follows:

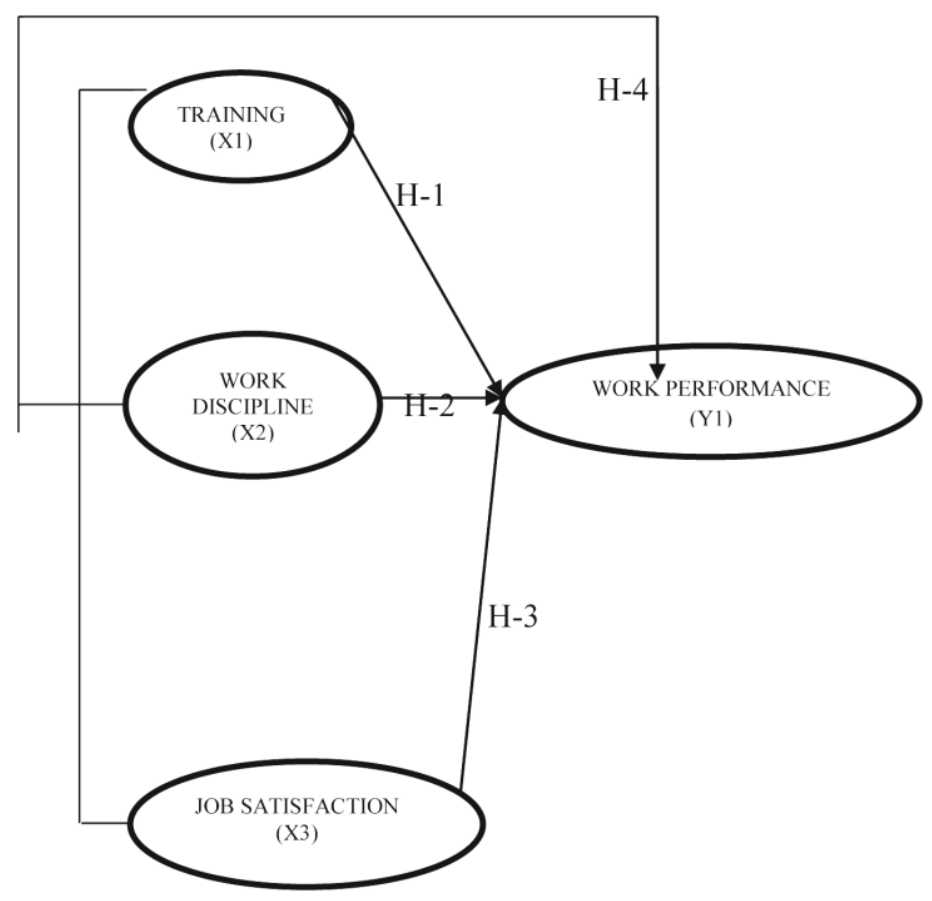

Figure 1. Conceptual framework

\section{Research Methods}

\subsection{Population and Sample}

the population of this study are members of the organization are members of the Association of Kindergarten Teachers Indonesia (IGTKI) District of Krembung totaling 98 members. And the sample size in this study are based on the opinions Arikunto (2010, p. 174) when the subject is less than 100, better all that research is the study population. Furthermore, if the major subject can be taken between $10-15 \%$ or $20-25 \%$ or more. 
Based on these opinions, because the population numbers less than 100, the researchers took samples of the whole number of 98 members of the organization. With a sample of this amount is expected to meet the requirements in sampling.

\subsection{Variables Research}

\subsubsection{The Independent Variable or the Independent Variable (X)}

According Sugiyono (2010, p. 39) independent variables are often called independent variables are variables that affect or that the cause of the change or the emergence of the dependent variable (dependent). The independent variables in this study were Education and Training (Training) as a variable (X1), Discipline Working as a variable (X2), and job satisfaction as a variable (X3).

\subsubsection{The Dependent Variable or the Dependent Variable (Y)}

According Sugiyono (2010, p. 39) Dependent variable is often referred to as the dependent variable, is a variable that is affected or which become due because of the avariabel free. The dependent variable of this study is Job Performance (Y).

\subsection{Research Instruments}

In the collection of data needed, the authors use the method: Questionnaire, where as measurements by using a variable interval scale by giving a score on the answer and measurement techniques using techniques Likert scale, whereas the author's technique using multiple linear regression analysis with the help of computer program SPSS.

\section{Analysis and Discussion}

\subsection{Data Analysis}

Multiple linear regression analysis used in this study to determine the effect of Education and Training (X1), Work Discipline (X2), and job satisfaction (X3) against members of the organization Job Performance IGTKI District of Krembung. To simplify the calculation, use SPSS software version 20.0, in order to obtain the following output:

Table 1. Multiple regression analysis

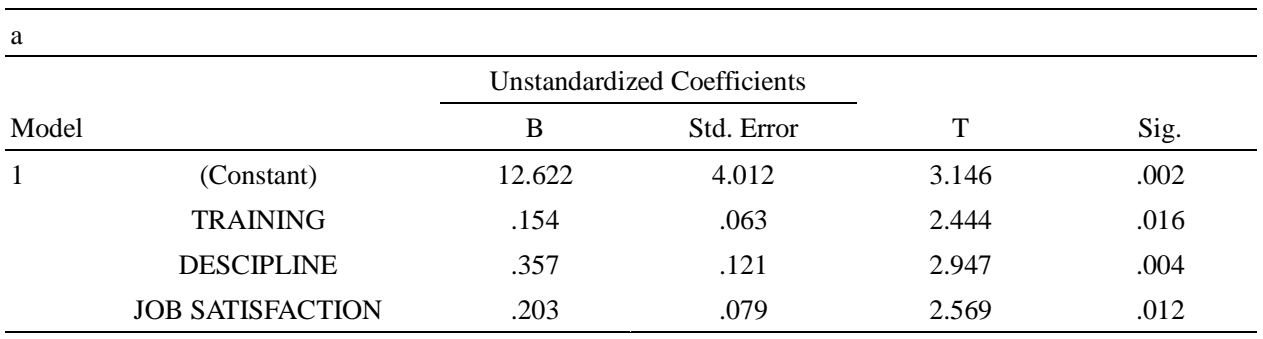

a. Dependent Variable: Achievements

\begin{tabular}{ccccccccc}
\hline & & & \multicolumn{6}{c}{ Model Summary $^{\mathbf{b}}$} \\
\cline { 4 - 7 } Model & $\mathrm{R}$ & R Square & R Square Change & F Change & df1 & df2 & Sig. F Change & Durbin-Watson \\
\hline & $.628^{\mathrm{a}}$ & .584 & .584 & 7.045 & 3 & 94 & .000 & 2.077 \\
\hline
\end{tabular}

a. Predictors: (Constant), Job Satisfaction, Training, Descipline.

b. Dependent Variable: job satisfaction.

Based on the analysis in the above table, the model obtained regression equation as follows:

$$
Y=12,622+0,154 X 1+0,357 X 2+0,203 X 3
$$

The multiple linear regression model explains things as follows:

1). Constant of 12.622 is the intersection of the regression line with the Y-axis shows the level of performance when all the independent variables, namely training (X1), work discipline (X2), and job satisfaction (X3) to 0 .

2). Variable training (X1) has a regression coefficient is positive, transformational leadership means if the 
variable increases by one unit the Work achievement $(\mathrm{Y})$ increased by the value of regression coefficient is 0.154 ; assuming other variables remain.

3). Variable labor discipline (X2) has a positive regression coefficient, meaning if work discipline variable increases by one unit then the work performance $(\mathrm{Y})$ increased by the value of regression coefficient is 0.357 ; assuming other variables remain.

4). Variable job satisfaction (X3) has had a positive regression coefficient, meaning that if the variable job satisfaction increased by one unit then the work performance $(\mathrm{Y})$ increased by the value of regression coefficient is 0.203 ; assuming other variables remain.

\section{Hypothesis Testing}

\subsection{Simultaneous Test (Test f)}

F test used in this study to test the hypothesis simultaneous truth of the independent variable on the dependent variable To simplify the calculation, use SPSS software version 20.0, in order to obtain the output in the table as follows:

Table 2. Uji $f$

\begin{tabular}{llccccc}
\hline \multicolumn{7}{c}{ ANOVA $^{\mathbf{b}}$} \\
\hline Model & & Sum of Squares & df & Mean Square & F & Sig. \\
\hline 1 & Regression & 122.110 & 3 & 40.703 & 7.045 & $.000^{\text {a }}$ \\
& Residual & 543.083 & 94 & 5.777 & & \\
& Total & 665.194 & 97 & & & \\
\hline
\end{tabular}

a. Predictors: (Constant), job satisfaction, training, discipline.

b. Dependent Variable: Achievements.

Based on the analysis in Table 2 obtained significance value of $0.000<0.05$. These results suggest that the variables of training, work discipline and job satisfaction are tested simultaneously to variable affects employee performance.

\subsection{Partial Test (T Test)}

$\mathrm{T}$ test in this study to determine which independent variables that affect performance. To simplify the calculation, use SPSS software version 20.0, in order to obtain the following output:

Table 3. Uji $t$

\begin{tabular}{|c|c|c|c|c|c|}
\hline \multicolumn{6}{|c|}{ Coefficients $^{\mathrm{a}}$} \\
\hline & & \multicolumn{2}{|c|}{ Unstandardized Coefficients } & \multirow[b]{2}{*}{$\mathrm{T}$} & \multirow[b]{2}{*}{ Sig. } \\
\hline \multicolumn{2}{|c|}{ Model } & B & Std. Error & & \\
\hline \multirow[t]{4}{*}{1} & (Constant) & 12.622 & 4.012 & 3.146 & .002 \\
\hline & training & .154 & .063 & 2.444 & .016 \\
\hline & descipline & .357 & .121 & 2.947 & .004 \\
\hline & Job satisfaction & .203 & .079 & 2.569 & .012 \\
\hline
\end{tabular}

a. Dependent Variable: Achievements.

Based on the table above can be seen that the variables of training, discipline and performance variables affect the performance of members. It is obtained from the significant value obtained in the variable training, discipline and satisfaction variables less than alpha (0.05). Values obtained in the variable training is $0.016<0.05$ in the discipline variable is $0.004<0.05$, and the satisfaction variables, namely $0.012<0.05$.

\section{Discussion}

Based on the analysis performed using multiple linear regression with the help of the program statistical version 20.0 is obtained in the model table summary that the price correlation coefficient of $R=0.628$ indicating that there is a strong relationship between the variables X1, namely training, X2 discipline, and X3 satisfaction with the variable $\mathrm{Y}$ is performance. 
In the model table summary that R2 (R Square) of 0.584 . This shows that the independent variables, namely training, discipline, and the satisfaction of the dependent variable that can affect work performance of 58.4\%. Coefficients in the table can be seen that the value for the variable of Education and Training (Training) is equal to 0,016; Work Discipline for the variable of 0.004; and Job Satisfaction of 0,012. From the data analysis using $t$ test, all variables generate significant value (Sig) $<0.05$; so this shows that Ho is rejected and Ha accepted, which means that the coefficient of multiple determination (R2) is significant.

Based on the analysis above, the results of research there are some things in accordance with the hypothesis as follows:

1). From the first hypothesis that the variables Education and Training (Training) positively and significantly affect the achievement of the organization's members work IGTKI District of Krembung, it is indicated by sig $t$ $0.016<0.05$.

2). From the second hypothesis that the variable Work Discipline positively and significantly affects the organization's members IGTKI Job Performance village Krembung it is shown with sig t $0.004<0.05$.

$3)$. From the third hypothesis that the variables job satisfaction positively and significantly affect the achievement of the organization's members IGTKI Subdistrict Work Krembung with sig t $0.012<0.05$.

4). From the fourth hypothesis that the Education and Training veriabel most dominant influence on Job Performance variables this can be evidenced by the results in the table that the value for the variable coefficients Work Discipline is equal to 0,016; Work Discipline for the variable of 0.004; and Job Satisfaction of 0,012.

\section{Conclusions and Suggestions}

\subsection{Conclusion}

Based on the analysis and hypothesis testing using SPSS version 20 of 98 respondents can be concluded that the hypothesis that the researchers propose that reads:

1). Education and Training (Training) significantly affects the organization's members work achievement IGTKI District of Krembung.

2). Work Discipline significant effect on Job Performance organization members IGTKI District of Krembung.

3). Job Satisfaction Job Performance significantly influence the members of the District Krembung IGTKI organization.

4). Of the three independent variables that have been studied, the variables Education and training is the most dominant variable in influencing members of the organization Job Performance IGTKI District of Krembung.

Furthermore unacceptable and unsubstantiated. This can be evidenced by the results of data analysis showed a correlation value $(\mathrm{R})$ of 0.628 which fall into the category has a very strong influence, and the value of determination R Square (R2) of 0.584 which means it has a very strong influence of $58.4 \%$. In the test results $\mathrm{f}$ there is positive and significant correlation between training, work discipline, and job satisfaction on job performance. For hypothesis testing using t that generate significant value (Sig.) Of 0,016 for education and training; 0,004 for the work discipline; and 0.012 for job satisfaction with a significance level of $5 \%$ or 0.05 so that the value of significance (Sig.) $<$ a significance level $(0.016<0.05$ for education and training; $0.004<0.05$ for work discipline; and $0.012<0.05$ for satisfaction work). These results indicate reject Ho and accept Ha.

\subsection{Suggestion}

From the above conclusion, researchers will provide advice to the members of the District IGTKI organization Krembung order to be considered by the board of the organization in carrying out the operational activities of the organization with the best. As for the suggestion that the researchers pointed out, among others:

1). The holding of training for members of the organization, especially the District Krembung IGTKI very important in realizing the goal of fluency in the organization, with the additional knowledge of the holding of training that teachers receive science and new knowledge in performing their duties so as to support the achievement of the organization's members work IGTKI District of Krembung.

2). Management of the organization should improve the discipline of members which includes attendance, adherence to labor laws and work ethically for members, so they can create a harmonious working relationship, convenient and a good sense of security among the members.

3). In the research that has do employee satisfaction already looks pretty good, so just pay attention to the board member job satisfaction is maintained so that the activities and goals of the organization can run smoothly. 
4). According to the research that the education and training received by members of the organization providing the highest contribution to job performance, it needs to be considered by the board of the organization and the District UPTD Krembung that a good work ethic that has been instilled in employees is maintained, and for employees who have no good ethics in order to be briefed of it, so that the level of labor productivity is expected to increase.

\section{References}

Arikunto, S. (2010). Procedures Research: A Practical Approach. Jakarta: Rineka Reserved.

Asmiarsih, T. (2006). Effect of Employee Work Discipline Supervision of the Office of the Regional Employment Board Bradford. Faculty of Social Sciences, University of Semarang.

Bendix, S. (2010). Industrial Relations in South Africa. Cape Town: Million \& Co. Ltd.

David, N. (1985). Performance Assessment and Employee Development. Jakarta: Rineka Reserved

Guntur. (1996). Workers'Social Security. Jakarta: Erland.

Grogan, J. (2009). Workplace Law. Cape Town: Million \& Co. Ltd.

Hani, T. H. (1994). Personnel Management and Human Resources. Jakarta: BPFE

Hani, T. H. (1997). Basics of Production Management and Communication. Yogyakarta: BPFE

Hani, T. H. (2002). Human Resource Management. Yogyakarta: BPFE

Hamalik, O. (2007). Human Resources Development and Employment Training Administration. Jakarta: Earth Literacy.

Hasibuan, M. S. P. (2005). Management Basics, Understanding, and Problems. Jakarta: Earth Literac

Hersey, B. (1992). Organizational Behavior Management (Human Resource Empowerment). Jakarta: Erland

Wursanto, I. G. (2014). Management Personnel. Retrieved from http://artikel-management.blogspot.com/2009/06/comprehension-employeejobsatisfaction.html

Jasin. (1996). Development of Self-Discipline. Jakarta: Mighty King Grafindo.

Kartini, K. (2003). Introduction to Research Methodology. Bandung: PT Alumni.

Lexi, J. M. (2002). Management Qualitative Research. Bandung: PT Youth Rosda paper.

Mangkunagara, A. (2006). Performance Evaluation of Human Resources. Bandung: PT Refika Aditama.

Mannulang, M. (2000). Human Resource Management. Yogyakarta: BPFE.

Mannulang, M. (2006). The Personnel Management. Jakarta: Ghalia Indonesia.

Martoyo, C. K., \& Susilo, S. E. (2000). Human Resource Management. Yogyakarta: BPFE.

Pearl. (2004). Human Resource Management. Bogor: Ghalia Indonesia.

Moekijat. (1991). Training and Human Resources Development. Bandung: Mandar forward.

Moekijat. (2005). Basics Motivation. Bandung: Wells Bandung.

Moses, M. (2011). The Effect of Education and Training hierarchical arrangements towards Job Performance Employees at the Department of Cooperatives and SMEs Jayapura City.

Nitisemito, A. S. (1984). Personnel Management (Human Resource Management). Jakarta: Ghalia Indonesia

Priyono. (2011). Human Resource Management. Surabaya: Dharma Science Press.

Rao, V. S. P. (2009). Organisational Behaviour. New Delhi: Excel Books.

Rival, V. (2006). Human Resource Management for the Company. Jakarta: Erland.

Ruki. (2002). Management Salary and Wage for Employees of the Company. Jakarta: Gramedia Pustaka Utama.

Robbins, S. (2002). Organizational Behavior. Jakarta: PT Gramedia Index.

Robbin, S. P., Odendaal, A., \& Roodt, G. (2003). Organisational behavour: Global and Southern African Perspective. Cape Town: Pearson Education South Africa.

Rokhmawati, P. (2013). Analysis of Employee Job Performance Assessment.

Sarwono, J. (2005). Research Data Analysis Using SPSS. Yogyakarta

Sastrohadiwiryo, S. (1989). Administrative and Operational Approach. Jakarta: Earth Literacy. 
Sastrohadiwiryo, S. (2005). Workforce Management Indonesia (2nd ed.). Jakarta: Earth Literacy.

Sugiyono, S. A. (2004). Business Research Methods. Bandung: Alfabeta.

Sugiyono, S. A. (2010). Educational Research Methods: Quantitative Approach. Qualitative and R \& D, Bandung: Alfabeta.

Sugiyono, S. A. (2015). Theory and Application for Data Analysis Research (Easy Ways to Learn SPSS and lisrel). To mold-1. Bandung: Alfabeta

Suhartono, T. (2008). The Influence of Motivation and Discipline Work on employee performance Pos Indonesia (Persero). Thesis Management PGRI Adi Buana University of Surabaya.

Usman, H. (2006). Management Theory, Practice and Research Education. Jakarta: Earth Literacy.

Venter, R., \& Levy, A. (2011). Labour relations in South Africa. Cape Town: Oxford University Press.

\section{Copyrights}

Copyright for this article is retained by the author(s), with first publication rights granted to the journal.

This is an open-access article distributed under the terms and conditions of the Creative Commons Attribution license (http://creativecommons.org/licenses/by/3.0/). 